\title{
Calcium phosphate-alginate microspheres as enzyme delivery matrices
}

\author{
C.C. Ribeiro, C.C. Barrias, M.A. Barbosa
}

\begin{abstract}
The present study concerns the preparation and initial characterisation of nov el calcium titanium phosphate-alginate (CTPalginate) and hydroxyapatite-alginate (HAp-alginate) microspheres, which are intended to be used as enzyme delivery matrices and bone regeneration templates. Microspheres were prepared using different concentrations of polymer solution ( $1 \%$ and $3 \% \mathrm{w} / \mathrm{v})$ and different ceramic-to-polymer solution ratios $(0.1,0.2$ and $0.4 \mathrm{w} / \mathrm{w})$. Ceramic powders were characterised using X-ray diffraction, laser granulometry, Brunauer, Emmel and Teller (BET) method for the determination of surface area, zeta potential and Fourier transform infrared spectroscopy (FT-IR). Alginate was characterised using high performance size exclusion chromatography. The methodology followed in this investigation enabled the preparation of homogeneous microspheres with a uniform size. Studies on the immobilisation and release of the therapeutic enzyme glucocerebrosidase, employed in the treatment of Gaucher disease, were also performed. The enzyme was incorporated into the ceramic-alginate matrix before gel formation in two different ways: preadsorbed onto the ceramic particles or dispersed in the polymeric matrix. The two strategies resulted in distinct release profiles. Slow release was obtained after adsorption of the enzyme to the ceramic powders, prior to preparation of the microspheres. An initial fast release was achieved when the enzyme and the ceramic particles were dispersed in the alginate solution before producing the microspheres. The latter profile is very similar to that of alginate microspheres. The different patterns of enzyme release increase the range of possible applications of the system investigated in this work.
\end{abstract}

Keywords: Microspheres; Enzyme-delivery; Alginate; Hydroxyapatite; Calcium titanium phosphate

\section{Introduction}

Osseous tumours, trauma and other debilitating diseases can create a need to fill defects in the skeleton. Most bone tissue engineering strategies rely on the use of temporary scaffolds that can be seeded with cells prior to implantation, or designed to induce the formation of bone from the surrounding tissue after implantation [1,2]. The effectiv eness of such materials can be highly improved if they can simultaneously act as drug deliv ery systems. Depending on the specificity of the illness, bioactive agents (e.g. growth factors or other protein-drugs) can be locally released and potentially accelerate the process of bone regeneration.

In the past few years, increasing efforts hav e been dev wed to the dev elopnent of improv ed injectable materials aimed at providing an alternative for the filling of bone defects with less patient discomfort, as they can be applied through minimally inv asiv esurgical procedures. Most injectable materials described in the literature consist of pastes, gels or liquid precursors that solidify in situ in response to some stimulus [3]. Micro- or nano-particles have also been described, but they must be suspended in either autologous blood or other appropriate vehicle prior to injection.

A $v$ ariety of injectable materials, both ceramic- and polymer-based, have been developed for use in multiple orthopaedic applications [4-20]. The combination of ceramic particles with polymeric matrices has also been extensiv ely inv estigated, in an attempt to mimic bone 
tissue, which may itself be seen as a complex composite material made of organic and inorganic components. Different ceramic phases have been used, hydroxyapatite and tricalcium phosphate being the most common [4-9], as well as several polymeric matrices, both from synthetic [10-14] or natural origin, the latter including collagen, chitosan, gelatine and alginate, among others [15-20].

This investigation describes the preparation and initial characterization of novel calcium titanium phosphate-alginate (CTP-alginate) and hydroxyapatitealginate (HAp-alginate) microspheres intended to be used as injectable enzyme delivery matrices and bone filling materials.

CTP is a bioactive ceramic currently under investigation in our laboratory [21]. Its properties, namely the capacity of ion exchange and chemical adsorption [22], and the ability to act as an immobilisation matrix for several enzymes [23], suggest that it can successfully be used in the biomedical field. Furthermore, recent in vivo studies showed direct bone contact of implanted cylinders containing calcium titanium phosphate as the main phase [24]. HAp, which has long been recognised for its bioactivity and osteoconductive properties and has been extensively tested as matrix in drug delivery applications [25,26], was also used in the present investigation.

Alginate was chosen as the polymeric vehicle due to its useful properties and versatility. Ultra-pure grade alginates are considered biocompatible and biodegradable and have been widely used in many biomedical applications, not only as vehicles for biologically active molecules [27] or cells, but also as scaffolds for tissue engineering, either as porous structures [28] or modified with RGD-containing peptide sequences [29]. Sodium alginate and most other alginates from monovalent metals are soluble in water, forming solutions of considerable viscosity. Due to their suitable rheological properties, alginates have long been used in the pharmaceutical industry as thickening or gelling agents, as colloidal stabilisers and as blood expanders [30].

$\mathrm{CTP}$-alginate and HAp-alginate microspheres were prepared using the droplet extrusion method. The ceramic granules were mixed with alginate enabling the preparation of spherical particles through instantaneous crosslinking in the presence of $\mathrm{Ca}^{2+}$ [30]. Compared to other methods of preparation of ceramic-polymer microspheres [31-33], this process presents the advantage of being simple and of being carried out at room temperature and in the absence of organic solvents, which makes it suitable for enzyme entrapment purposes. Moreover, the spherical particles can be easily recovered, without the need for fastidious washing processes, and present a regular size distribution even without subsequent fractionation by sieving.
Analysis of the ability of these matrices to act as carriers for the enzyme glucocerebrosidase (GCR) was also undertaken. This enzyme is used in the treatment of Gaucher disease (type I), which is characterised by a number of severe disabling symptoms, including bone pathologies [34]. GCR is highly unstable in solution under physiological conditions [35]. Its immobilisation is currently under investigation in our group to overcome this problem.

\section{Materials and methods}

\subsection{Materials}

Calcium titanium phosphate (CTP) was synthesised by solid state reaction as described elsewhere [21]. Commercial hydroxyapatite (HAp) powder (CAM Implants) pre-heated at $1000^{\circ} \mathrm{C}$ was used as a reference. Pharmaceutical-grade sodium alginate (Protanal 10/60 LS) with a high $\alpha$-L-guluronic acid content $(65-75 \%$, as specified by the manufacturer) was kindly donated by Pronova Biopolymers and used without further purification. Na-alginate solutions were prepared fresh as needed, using bi-distilled deionised water. Purified recombinant human glucocerebrosidase (GCR) was purchased from Genzyme Corporation as a lyophilised powder. $\mathrm{Na}^{125} \mathrm{I}$ and Sephadex columns were purchased from Amersham Pharmacia Biotech. Additional chemicals were purchased from Sigma.

\subsection{Characterisation of CTP and HAp powders: X-ray} diffraction, specific surface area, granulometry and zeta potential determination

The ceramic powders were analysed by X-ray diffraction (XRD, Philips PW 1710 diffractometer) and their specific surface area was measured by gas adsorption according to the Brunauer, Emmel and Teller (BET) method. Granulometric analysis was performed using a laser scanner particle size analyser (Coulter Electronics Incorporation). Zeta potential (ZP) of CTP and HAp powders was measured with a Coulter Delsa 440 instrument. ZP was calculated automatically by the instrument based on the Smoluchowski formula:

$\zeta=4 \pi \frac{\mu \eta}{E}$,

where $\zeta$ is the $\mathrm{ZP}(\mathrm{mV}), \mu$ the electrophoretic mobility $(\mu \mathrm{m} \mathrm{cm} / \mathrm{V} \mathrm{s}), \eta$ the viscosity of the fluid, and $E$ the dielectric constant of the fluid. The principle of electrophoresis is that a particle will move in a liquid under the influence of an applied electric field provided its $\mathrm{ZP}$ is different from zero. The electrophoretic mobility is proportional to the $\mathrm{ZP}$ as shown in the equation above. 
The ZP of CTP and HAp powders were determined at several $\mathrm{pH}$ values. The powders were dispersed in $10 \mathrm{~mm}$ $\mathrm{KCl}$ and the $\mathrm{pH}$ was adjusted with $0.1 \mathrm{M} \mathrm{HCl}$ and $0.1 \mathrm{M}$ $\mathrm{KOH}$.

\subsection{Characterisation of alginate by HP-SEC}

High performance size exclusion chromatography (HP-SEC) was performed at room temperature using a modular system, composed of an isocratic pump (K1001 Knaeur), a vacuum degasser (K-5002 Knaeur), a viscometer/right angle laser light scattering (RALLS) dual detector (T60 Viscotek), and a refractive index detector (K-5002 Knaeur) operating at the same wavelength as the RALLS detector $(670 \mathrm{~nm})$. Separations were performed in a set of PL aquagel-OH mixed columns. The mobile phase consisted of $0.1 \mathrm{M} \mathrm{NaNO}$ with $0.02 \% \mathrm{w} / \mathrm{v} \mathrm{NaN}$ and the flow-rate was maintained at $1.0 \mathrm{ml} / \mathrm{min}$. Samples were dissolved in the mobile phase, filtered and injected through a manual injection valve equipped with a $116 \mu$ loop.

\subsection{Preparation of CTP-alginate and HAp-alginate microspheres}

CTP or HAp powders were dispersed in a pre-filtered $(0.8 \mu \mathrm{m}) \mathrm{Na}$-alginate solution under gentle stirring until a homogeneous paste was obtained. Different concentrations of the polymer solution $(1 \%$ and $3 \% \mathrm{w} / \mathrm{v})$, and different ceramic-to-polymer solution ratios $(0.1,0.2$ and $0.4 \mathrm{w} / \mathrm{w}$ ) were tested. These will be designated as $10 /$ 1, 20/1, 40/1 (ceramic-to-polymer solution ratios, using the $1 \% \mathrm{w} / \mathrm{v}$ Na-alginate solution) and 10/3, 20/3, 40/3 (ceramic-to-polymer solution ratios, using the $3 \% \mathrm{w} / \mathrm{v}$ Na-alginate solution). The pastes were extruded dropwise into a $0.1 \mathrm{M} \mathrm{CaCl}_{2}$ crosslinking solution, where spherical-shaped particles instantaneously formed and were allowed to harden for $30 \mathrm{~min}$. The size was controlled by regulating the extrusion flow rate using a syringe pump (Cole-Parmer), and by applying a coaxial air stream (Encapsulation Unit Var J1-Nisco). At completion of the gelling period the microspheres were recovered and rinsed in water in order to remove the excess $\mathrm{CaCl}_{2}$. Finally, they were dried overnight in a vacuum oven at $30^{\circ} \mathrm{C}$. The diameter of the microspheres was measured using an inverted plate microscope (Olympus) equipped with an ocular micrometer with an accuracy of $10 \mu \mathrm{m}$.

\subsection{Characterisation of CTP-alginate and HAp-alginate microspheres: SEM and FT-IR analysis}

Morphological characterisation of the microspheres (surface and transversal sections obtained by criofracture in liquid nitrogen) was carried out using scanning electron microscopy (SEM). Samples were sputter coated with gold using a JEOL JFC-100 fine coat ion sputter device, and observed using a JEOL JSM-6301F scanning microscope.

Physical chemical characterisation of the microspheres and their components (CTP, HAp and Caalginate) were analysed by Fourier transform infrared spectroscopy (FT-IR) using a Perkin Elmer system 2000 spectrometer. The FT-IR spectrum of Na-alginate was also obtained and used as a reference. Microspheres were reduced to powder and were analysed as $\mathrm{KBr}$ pellets.

\subsection{Enzyme immobilisation in CTP-alginate and HAp- alginate microspheres}

The enzyme was incorporated into the ceramicalginate microspheres (formulation 20/3) before gel formation in two different ways: pre-adsorbed onto the ceramic particles before mixing with the alginate solution, or dispersed in the polymeric-ceramic paste. Microspheres were subsequently prepared as previously described, without drying. In Fig. 1 a schematic representation of the matrices tested is presented. The matrices $\mathrm{A}$ and $\mathrm{B}$ were used as controls.

\subsubsection{Pre-adsorption of the enzyme onto CTP and HAp powders}

A solution containing glucocerebrosidase (GCR) was obtained by dissolving the enzyme in phosphate buffered saline (PBS, $\mathrm{pH}$ 7.4) at a final concentration of $0.2 \mathrm{mg} / \mathrm{ml}$ and in the presence of $0.5 \mathrm{mg} / \mathrm{ml}$ of bovine serum albumin (BSA) as a stabiliser. The solution also contained radiolabeled $\left({ }^{125} \mathrm{I}\right)$ enzyme (Iodogen method) as a tracer and $0.01 \mathrm{~m} \mathrm{NaI}$ to competitively reduce binding by any free ${ }^{125} \mathrm{I}$ species present. The specific radioactivity of the solution was $6.5 \times 10^{7} \mathrm{cpm} / \mathrm{mg}$ GCR.

For the adsorption tests, CTP and HAp powders $(50 \mathrm{mg})$ were incubated with $500 \mu \mathrm{l}$ of the enzyme solution. Samples were maintained at $4{ }^{\circ} \mathrm{C}$ in an orbital shaker at $250 \mathrm{rpm}$. At predefined time intervals, samples were centrifuged $(14,000 \mathrm{rpm}, 5 \mathrm{~min})$ and the supernatants collected for analysis. The powders were washed twice with PBS and separated by centrifugation. The powders and all the supernatants were counted for radioactivity. The counts of each sample were averaged and the surface concentration was calculated by the equation:

$\operatorname{GCR}\left(\mathrm{ng} / \mathrm{cm}^{2}\right)=\frac{\text { Counts }(\mathrm{cpm})}{A_{\text {solution }}(\mathrm{cpm} / \mathrm{ng}) \times \mathrm{SA}\left(\mathrm{cm}^{2}\right)}$,

where the counts represent the radioactivity of the powders, the $A_{\text {solution }}$ is the specific activity of the protein solution and SA is the surface area of the powders, which was calculated as described previously. 


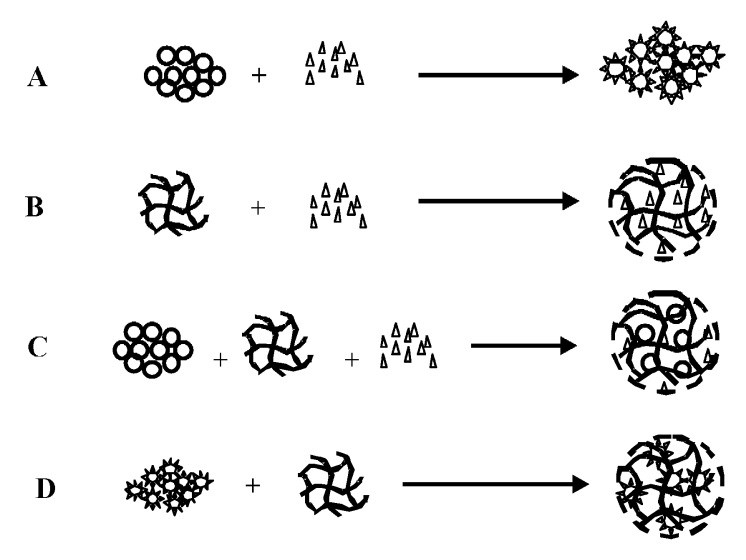

$a_{\Delta}^{\Delta} \Delta_{\Delta}^{A} A_{\Delta}$ Glucocerebrosidase

Fig. 1. Different enzyme immobilisation matrices tested: (A) enzyme adsorbed onto the ceramic powders, (B) enzyme dispersed in a pure alginate matrix, (C) enzyme and ceramic powders individually dispersed in the alginate matrix and (D) ceramic powders with pre-adsorbed enzyme dispersed in the alginate matrix. Matrices $A$ and $B$ were used as controls.

\subsection{Enzyme release studies}

Enzyme release studies were performed in PBS. Samples $(n=3)$ were maintained at $37 \pm 0.2^{\circ} \mathrm{C}$ in an orbital shaker at $120 \mathrm{rpm}$. At predefined time intervals, the supernatants were collected and counted for radioactivity and fresh PBS was added. In the case of the powder matrices (Fig. 1, matrix A) samples were centrifuged $(14,000 \mathrm{rpm}, 5 \mathrm{~min})$ prior to collecting the supernatants. At the end, the matrices were recovered, washed twice with PBS and counted for residual radioactivity.

\section{Results}

\subsection{Characterisation of CTP and HAp powders}

\subsubsection{X-ray diffraction and specific surface area}

$\mathrm{X}$-ray diffraction analysis of the ceramics indicated the presence of mono phase crystalline compounds. The specific surface areas obtained using the BET method were $9.84 \mathrm{~cm}^{2} / \mathrm{mg}$ for the CTP powder and $76.00 \mathrm{~cm}^{2} / \mathrm{mg}$ for the HAp.

\subsubsection{Granulometric analysis}

The granulometric analysis of HAp and CTP powders is presented in Figs. 2a and b, respectively. The particle size distribution curves of both ceramics are narrow. In the case of the CTP powder $90 \%$ (in volume) of the particles are smaller than $25.32 \mu \mathrm{m}$ and have a volume average diameter of $11.00 \mu \mathrm{m}$. In the HAp powder $90 \%$ of the particles are smaller than $20.51 \mu \mathrm{m}$ and the volume average diameter is $7.96 \mu \mathrm{m}$.

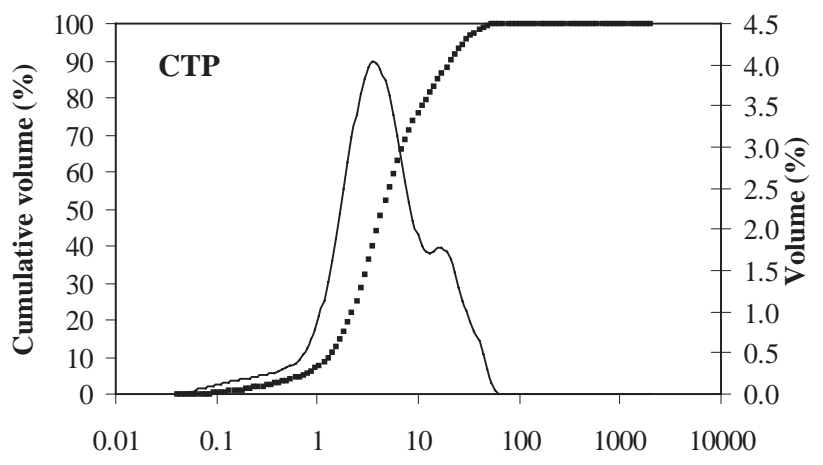

(a) Particle diameter $(\mu \mathrm{m})$

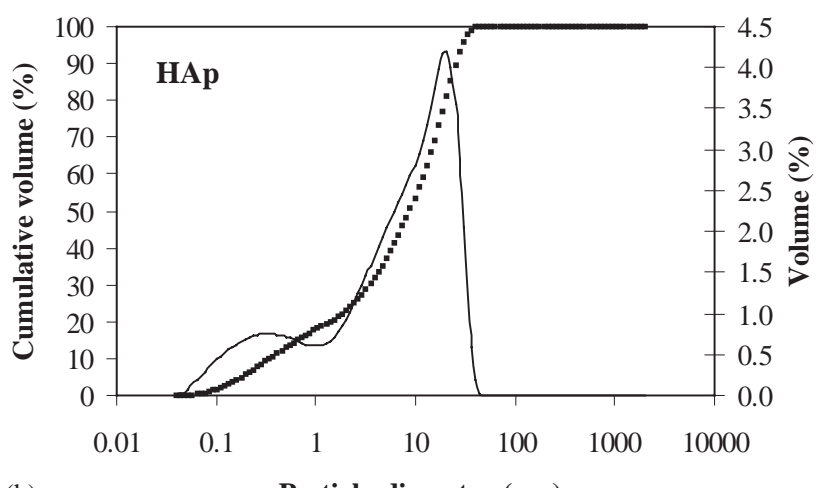

(b)

Particle diameter $(\mu \mathrm{m})$

Fig. 2. Granulometric analysis of (a) CTP and (b) HAp powders Cumulative (dashed line) and non-cumulative (solid line) volume percentage particle size distributions are plotted on the left and right axis, respectively.

\subsubsection{Zeta potential measurements}

ZP measurements of CTP and HAp powders as a function of $\mathrm{pH}$ are presented in Fig. 3. As can be observed, the isoelectric point of CTP occurs 


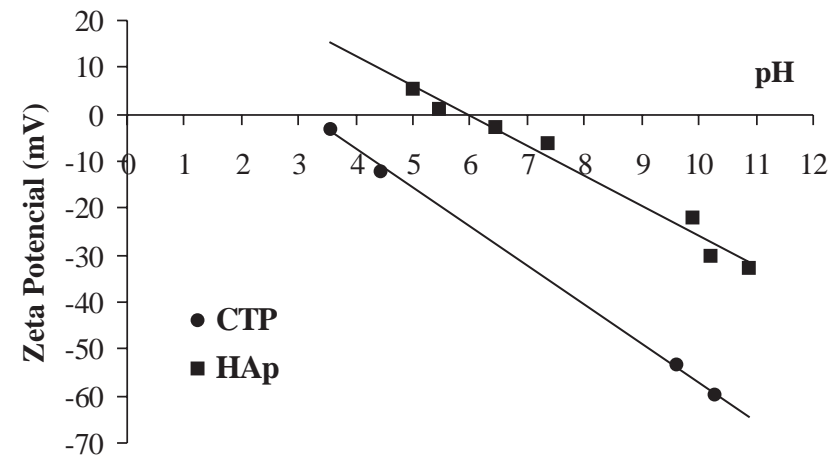

Fig. 3. Zeta Potential of CTP and HAp powders as a function of $\mathrm{pH}$.

approximately at $\mathrm{pH} 3$ whereas the isoelectric point of HAp occurs approximately at $\mathrm{pH}$ 6. To the best of our knowledge, the isoelectric point of CTP has not been reported in the literature before. As far as the HAp is concerned, the results obtained are in agreement with those reported by other authors [36,37]. At physiological $\mathrm{pH}$ both ceramics are negatively charged, the CTP potential being more negative than that of HAp.

\subsection{Characterisation of alginate by HP-SEC}

The Na-alginate used in this study was characterised by an average molecular weight $\left(M_{\mathrm{w}}\right)$ of $1.3 \times 10^{5}$, a polidispersity index of 1.9 and an intrinsic viscosity of $6.4 \mathrm{dl} / \mathrm{g}$, as determined by HP-SEC.

\subsection{Characterisation of CTP-alginate and HAp-alginate microspheres}

CTP-alginate and HAp-alginate microspheres were prepared using different concentrations of the polymer solution $(1 \%$ and $3 \% \mathrm{w} / \mathrm{v})$, and different ceramic-topolymer solution ratios $(0.1,0.2$ and $0.4 \mathrm{w} / \mathrm{w})$. As soon as the ceramic-polymer droplets contacted with the crosslinking solution, spherical-shaped particles were instantaneously formed when using the $3 \% \mathrm{w} / \mathrm{v}$ alginate solution. An exception was observed for the HApalginate $40 / 3$ paste, which was too viscous to be extruded in a reproducible manner. Particles obtained using the $1 \% \mathrm{w} / \mathrm{v}$ alginate solution presented a discshaped morphology and for that reason were not used in the subsequent experiments.

The diameters of the microspheres obtained (before and after drying) using the $3 \% \mathrm{w} / \mathrm{v}$ polymer solution and the different ceramic-to-polymer ratios are presented in Fig. 4. Before drying, microspheres of approximately $1000 \mu \mathrm{m}$ were obtained when using pure alginate, CTP with alginate, and HAp with alginate. Upon drying, microspheres have undergone a volume contraction, which was more significant for the lower ceramic-topolymer solution ratio $(0.1 \mathrm{w} / \mathrm{w})$. Microspheres with

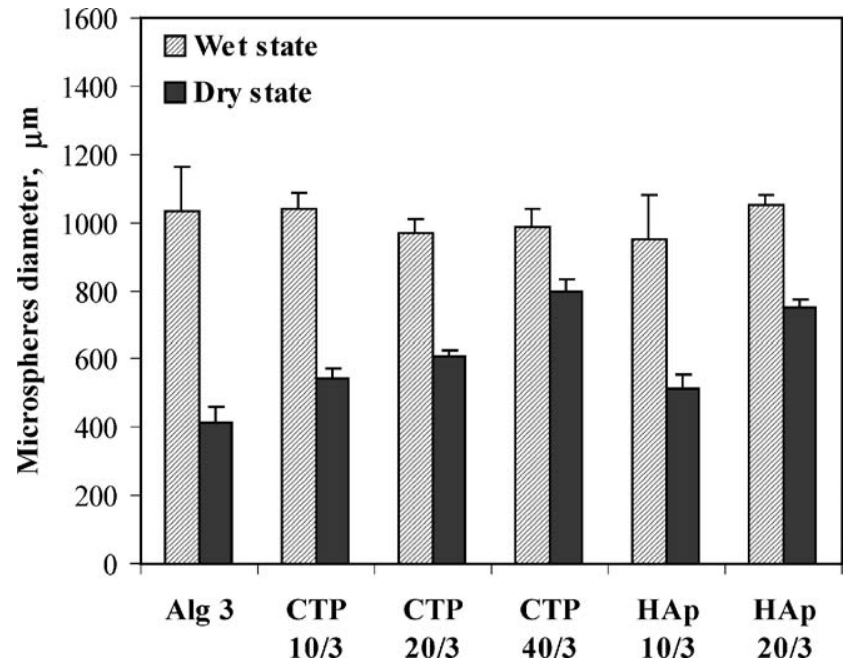

Fig. 4. Diameters of alginate, CTP-alginate and HAp-alginate microspheres prepared using the $3 \% \mathrm{w} / \mathrm{v}$ alginate solution, before (wet state) and after drying (dry state).

diameters of $541 \pm 32,606 \pm 21$, and $796 \pm 39 \mu \mathrm{m}$ were obtained for the CTP $10 / 3,20 / 3$ and $40 / 3$ formulations, respectively. When using HAp, microspheres with diameters of $512 \pm 44$ and $749 \pm 22 \mu \mathrm{m}$ were obtained for the $10 / 3$ and $20 / 3$ formulations.

\subsubsection{SEM analysis}

SEM images of the microspheres (20/3 formulations) are presented in Figs. 5 and 6. Upon drying, and contrary to alginate microspheres that shrank to a great extent and even collapsed (Fig. 5a), CTP-alginate (Fig. 5b) and HAp-alginate (Fig. 5c) microspheres maintained their original shape, with no evidence of cracks. This suggests that both fillers provided additional control of shrinkage and avoided structural collapse. Different surface roughnesses were obtained, those of the HApalginate microspheres being smoother than those of CTP-alginate.

The ceramic powders are homogenously distributed in the alginate matrix (Fig. 6) with the granules densely packed and well embedded in the polymer.

\subsubsection{FT-IR analysis}

FT-IR spectra of calcium and sodium alginate are represented in Fig 7. Table 1 shows the possible assignments for the FT-IR bands of the alginate salts [38]. Both spectra are very similar and only slight differences can be observed in the width and height of the $\mathrm{COO}^{-}$bands.

Fig. 8 shows the FT-IR spectra of CTP powder, Caalginate and CTP-alginate microspheres (formulations $10 / 3$ and $40 / 3$ ). The FT-IR spectra of HAp powder, $\mathrm{Ca}$-alginate and HAp-alginate microspheres (formulations $10 / 3$ and $40 / 3$ ) are presented in Fig. 9. The characteristic bands of both ceramics are maintained in 


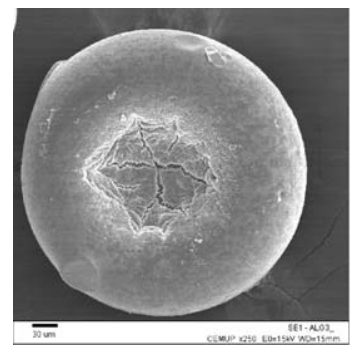

(a)

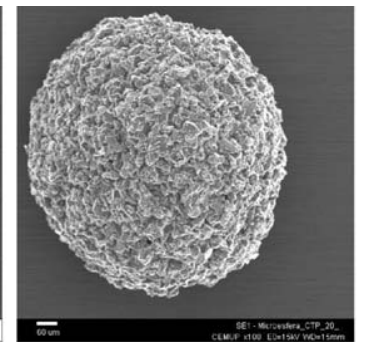

(b)

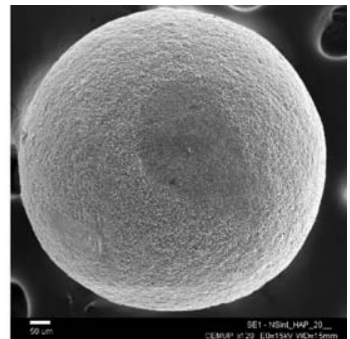

(c)

Fig. 5. SEM image of (a) Ca-alginate, (b) CTP-alginate and (c) HAp-alginate microspheres

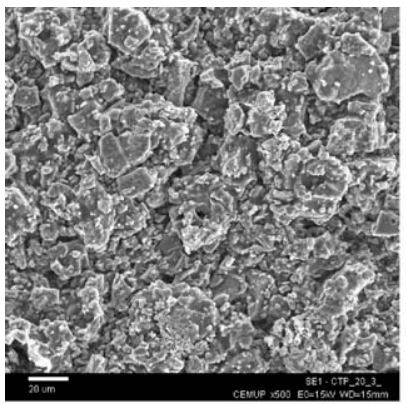

(a)

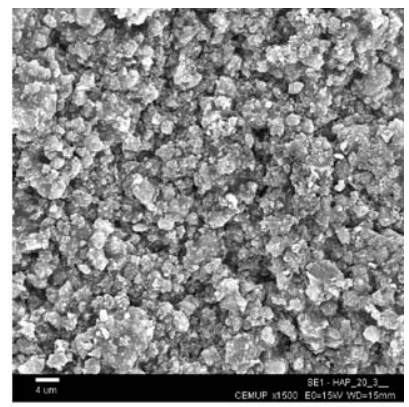

(b)
Fig. 6. Detail of a transversal section of CTP-alginate (a) and HApalginate (b) microspheres, showing that the ceramic particles are well embedded in the polymer matrix.

the microspheres indicating that the alginate did not induce subsequent modifications in the ceramics structure. Additional bands can be observed, corresponding to the presence of calcium alginate, namely at $3446 \mathrm{~cm}^{-1}$ $(v \mathrm{OH}), 1619$ and $1428 \mathrm{~cm}^{-1}\left(\nu \mathrm{COO}^{-}\right)$, and $820 \mathrm{~cm}^{-1}$, identified in the literature as the combination of three possible vibrational modes $(\tau \mathrm{CO}+\delta \mathrm{CCO}+\delta \mathrm{CCH})$ [38]. The intensity of these bands increases as the ceramic-topolymer solution ratio decreases. Also, the $v_{3} \mathrm{PO}_{4}$ region $\left(900-1200 \mathrm{~cm}^{-1}\right)$ becomes broader in the spectra of the microspheres, denoting the presence of the polymer.

\subsection{Enzyme immobilisation in CTP-alginate and HAp- alginate microspheres}

\subsubsection{Pre-adsorption of the enzyme onto CTP and HAp powders}

Fig. 10 shows typical adsorption time profiles of GCR onto CTP and HAp powders. The adsorption process was carried out at $4{ }^{\circ} \mathrm{C}$ for different periods of time (10, 120 and $1440 \mathrm{~min}$ ). For both ceramics there is an initial period of rapid adsorption followed by a slower approach to a limiting value. After $1440 \mathrm{~min}$, CTP adsorbed $41.28 \mathrm{ng} \mathrm{GCR} / \mathrm{cm}^{2}$, a much higher amount of enzyme per unit surface are than HAp (1.94 ng GCR/ $\mathrm{cm}^{2}$ ).

Fig. 11 represents the percentage of enzyme, with respect to the total amount used, which becomes adsorbed to the ceramic powders $(21 \%$ in the case of CTP and $10 \%$ in the case of HAp), as well as the percentage of enzyme that remains in solution after incubation. The percentage of enzyme removed from the solids during washing (first and second washes) is also represented. The percentages of $21 \%$ and $10 \%$ were measured after washing, indicating that the enzyme remained well adsorbed onto the powders.

\subsection{Enzyme release studies}

Fig. 12 shows the release profiles obtained for the different matrices previously described using CTP as the ceramic phase. The release profiles using HAp were similar (results not shown). When the enzyme was dispersed in the ceramic-alginate mixture before gel formation (matrix C), the release profile seems to be initially controlled by the diffusion of GCR from the surface of the beads, with a burst of $33.6 \pm 3.3 \%$ of total loading, followed by diffusion through the pores of the gel matrix until reaching a plateau at $55.4 \pm 4.6 \%$. The overall release profile was not significantly different from what was obtained using a pure alginate matrix (matrix B). When the enzyme was pre-adsorbed onto the ceramic powders prior to the preparation of the microspheres (matrix D), the initial burst was significantly reduced $(9.4 \pm 1.4 \%)$ and a slower release profile was obtained. The results obtained when using matrix A were similar to those reported for matrix D.

\section{Discussion}

CTP-alginate and HAp-alginate microspheres were prepared using the droplet extrusion method combined with ionotropic gel formation in the presence of $\mathrm{Ca}^{2+}$ [27]. Polymer-ceramic mixtures of different compositions were prepared and drop-wise extruded into a crosslinking solution containing $\mathrm{Ca}^{2+}$. As soon as the droplets contacted with the solution, spherical particles were instantaneously formed, due to the rapid establishment of calcium-mediated associations between poly guluronic acid sequences on the polymer backbone [27]. 


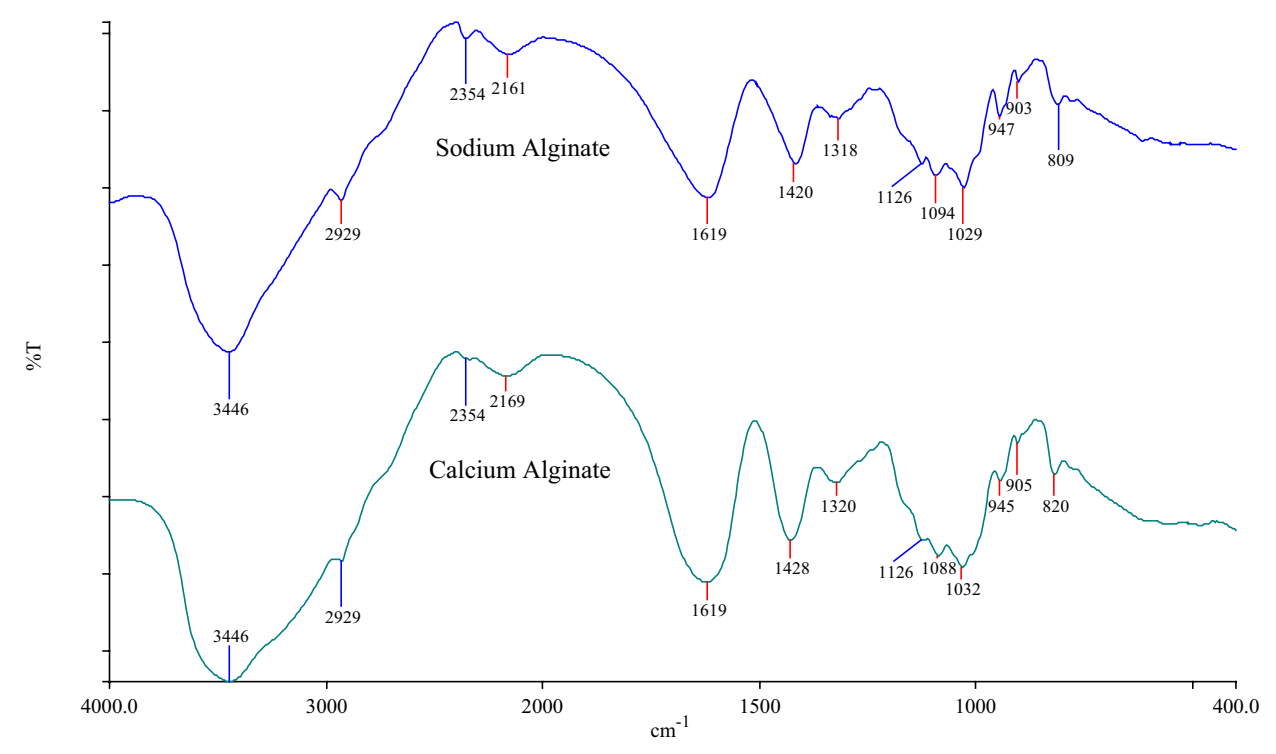

Fig. 7. FT-IR spectra of sodium and calcium alginate.

Table 1

Peak assignment of transmittance bands of Na-alginate and Ca-alginate spectra obtained by FT-IR

\begin{tabular}{llll}
\hline $\mathrm{Na} /$ Ca-alginate bands $\left(\mathrm{cm}^{-1}\right)$ & Peak Assignment $[36]$ & $\mathrm{Na} /$ Ca-alginate bands $\left(\mathrm{cm}^{-1}\right)$ & Peak Assignment $[36]$ \\
\hline 3446 & $v(\mathrm{OH})$ hydrogen bonded & 1126 & $v(\mathrm{CC}), v(\mathrm{CO})$ \\
2929 & $v(\mathrm{CH})$ & $1088 / 1094$ & $\tau(\mathrm{CO}), \delta(\mathrm{CCO}), \delta(\mathrm{CC})$ \\
2354 & - & $1029 / 1032$ & $\tau(\mathrm{CO}), \delta(\mathrm{CCO}), \delta(\mathrm{CC})$ \\
$2161 / 2169$ & - & $947 / 945$ & $v(\mathrm{CO}), \delta(\mathrm{CCH})$ \\
1619 & $v\left(\mathrm{COO}^{-}\right)$ & $903 / 905$ & $v(\mathrm{CO}), \delta(\mathrm{CCH})$ \\
$1420 / 1428$ & $v\left(\mathrm{COO}^{-}\right)$ & $809 / 820$ & $\tau(\mathrm{CO}), \delta(\mathrm{CCO}), \delta(\mathrm{CCH})$ \\
$1318 / 1320$ & $v\left(\mathrm{COO}^{-}\right)$ & & \\
\hline
\end{tabular}

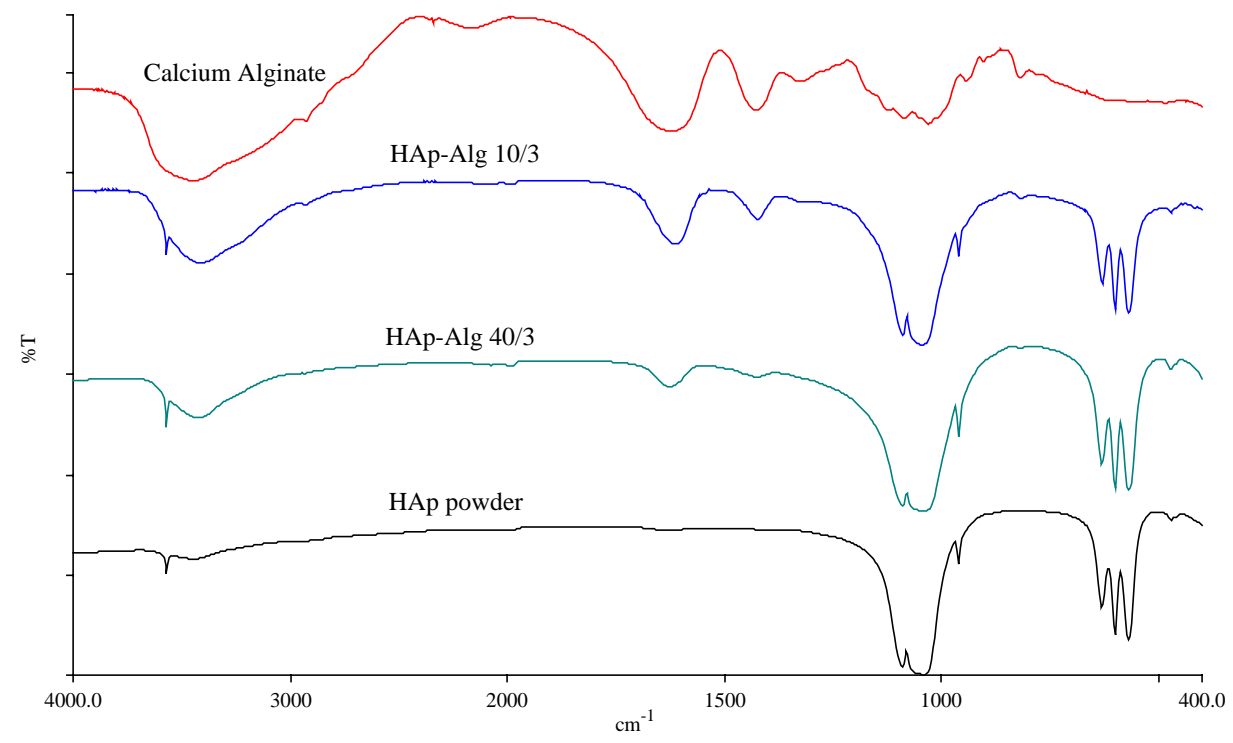

Fig. 8. FT-IR spectra of Ca-alginate, CTP-alginate $10 / 3$ and $40 / 3$ microspheres, and CTP powder.

This resulted in the formation of an alginate hydrogel network with entrapped ceramic particles.

The process was carried out at room temperature and in the absence of organic solvents, which is ideal for the envisaged applications of these materials as enzyme carriers.

The described methodology enabled the preparation of homogeneous microspheres presenting a regular size 


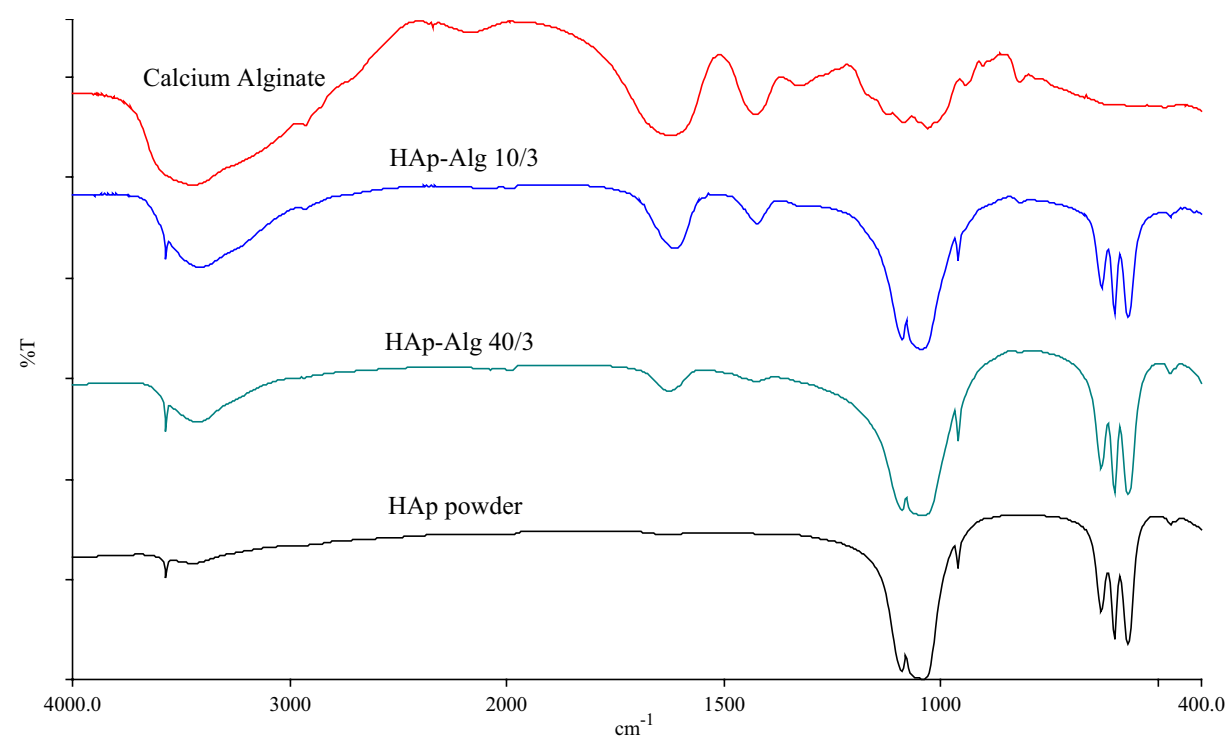

Fig. 9. FT-IR spectra of Ca-alginate, HAp-alginate $10 / 3$ and $40 / 3$ microspheres, and HAp powder.

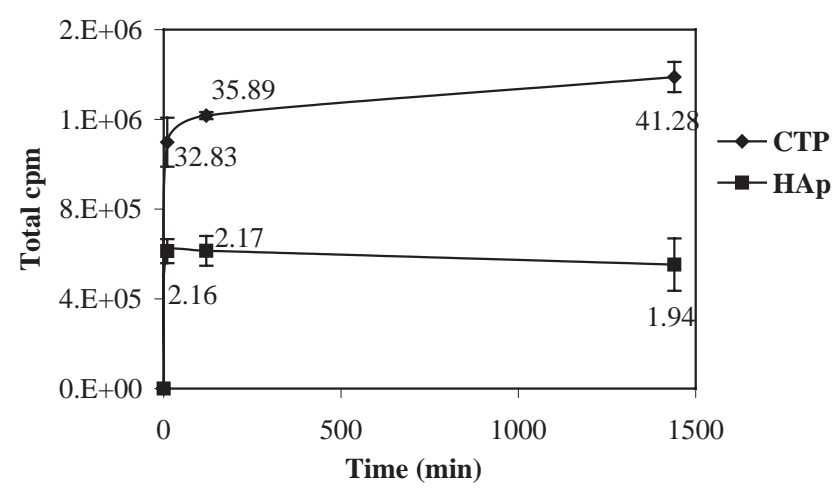

Fig. 10. Time profiles of glucocerebrosidase adsorption onto CTP and HAp powders. The adsorption process was carried out at $4{ }^{\circ} \mathrm{C}$ for different periods of time (10, 120 and $1440 \mathrm{~min})$. Data labels represent the amount of adsorbed protein per unit surface area $\left(\mathrm{ng} / \mathrm{cm}^{2}\right)$ of the powders.

distribution, even without being fractioned by sieving. During the drying process and depending on their composition, microspheres underwent volume contractions at different extents. Shrinkage is related to water loss from the polymeric hydrogel phase, explaining why formulations with high ceramic-to-polymer contents underwent less contraction.

SEM observation of the microspheres showed that the ceramic particles were well embedded and homogeneously distributed in the alginate matrix, suggesting a good wettability of the ceramics by the polymer solution. The surface morphology of the microspheres was dependent on the type of ceramic used, the HApalginate microspheres being smoother than the CTPalginate ones. Differences were essentially attributed to the different mean particle sizes of the two ceramic powders. Although the granulometric analysis revealed

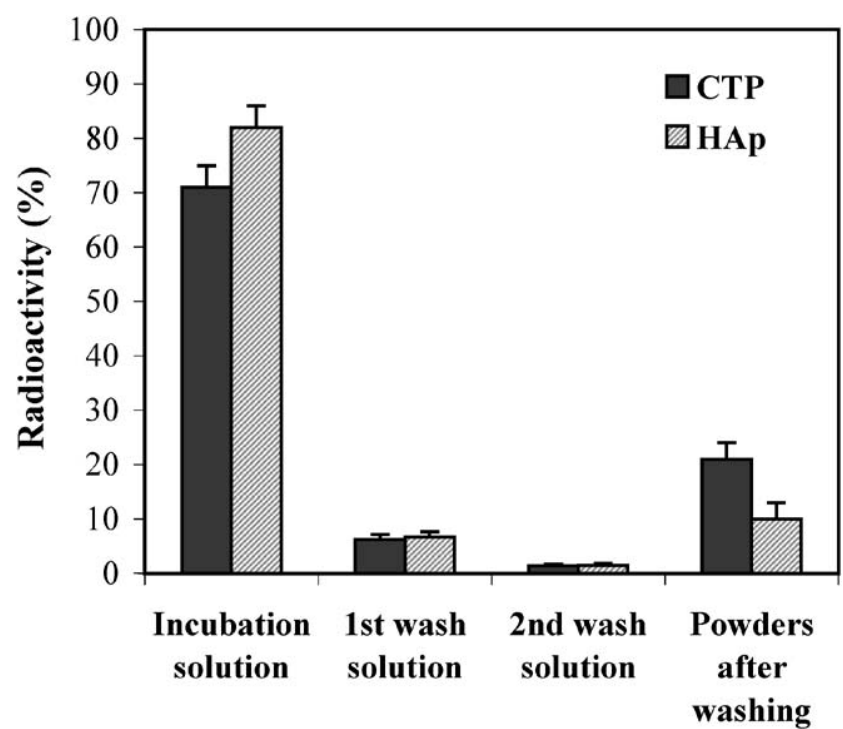

Fig. 11. Adsorption of glucocerebrosidase onto CTP and HAp powders: percentage of radioactivity that becomes associated to the powders after an incubation period of $10 \mathrm{~min}\left(4^{\circ} \mathrm{C}\right)$. The percentages of radioactivity that remain in the supernatant and are washed out from the powders are also depicted.

that the particles of both powders were similar in size (90\% of CTP particles are smaller than $25.32 \mu \mathrm{m}$ and have an average diameter of $11.00 \mu \mathrm{m}$, while $90 \%$ of the HAp particles are smaller than $20.51 \mu \mathrm{m}$ and the average diameter is 7.96), the surface area measurements indicated that HAp particles have a much higher surface area $\left(76 \mathrm{~cm}^{2} / \mathrm{mg}\right)$ than CTP $\left(9.8 \mathrm{~cm}^{2} / \mathrm{mg}\right)$.

Physico-chemical characterisation of CTP-alginate and HAp-alginate was carried out by FT-IR spectroscopy. The spectra showed that the characteristic bands of both ceramics are maintained in the microspheres, 


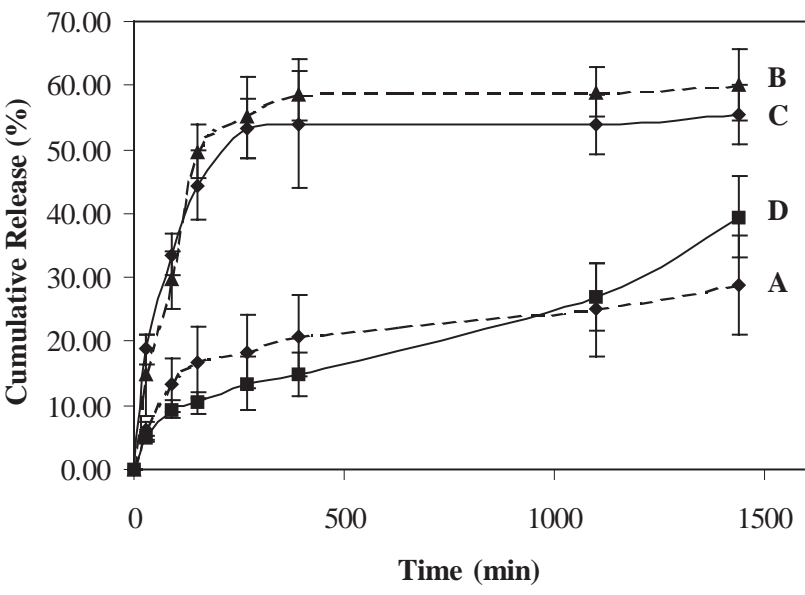

Fig. 12. Enzyme release profiles from the matrices tested using CTP: (A) enzyme adsorbed onto the ceramic powders; (B) enzyme dispersed in a pure alginate matrix; (C) enzyme and ceramic powders individually dispersed in the alginate matrix; and (D) ceramic powders with pre-adsorbed enzyme dispersed in the alginate matrix. The matrices $\mathrm{A}$ and $\mathrm{B}$ were used as controls.

indicating that the alginate did not induce subsequent modifications in the structure of the ceramics.

A preliminary analysis of the ability of CTP-alginate and HAp-alginate microspheres to act as carriers for the enzyme glucocerebrosidase (GCR), a therapeutic enzyme used in the treatment of Gaucher disease, was carried out.

The possibility of exploiting the capacity of both components to act as enzyme delivery systems was investigated, since both may immobilise proteins [2327]. For this reason, the enzyme was incorporated into the ceramic-alginate matrix before gel formation in two different ways, as described before. Concerning GCR loading capabilities of the ceramics used in this study, results showed that CTP adsorbs $41.28 \mathrm{ng} / \mathrm{cm}^{2}$, a much higher amount of enzyme per unit surface than HAp $\left(1.94 \mathrm{ng} / \mathrm{cm}^{2}\right)$. This may be attributed to the presence of BSA, used to stabilise the enzyme, as explained below. At physiological $\mathrm{pH}$, both ceramics are negatively charged, the zeta potential of CTP being more negative than that of HAp. At pH 7.4, the enzyme is in the vicinity of its isoelectric point exhibiting a neutral net charge. Under the conditions used, BSA presents a net negative charge [39] and will probably bind to a lesser extent to CTP than to HAp, due to increased repulsive charge, thus leaving the surface more available for GCR adsorption. Decreased adsorption of HSA (human serum albumin) onto CTP than onto HAp powders was observed by the authors (unpublished data), supporting this hypothesis. Despite being a very complex process, protein adsorption generally reflects hydrophobic/hydrophilic or electrostatic interactions between the protein and the surface. It seems that under the conditions used, the electrostatic characteristics of CTP favours the immobilisation of GCR.

Other authors, in studies concerning applications in the biotechnology industry [22], demonstrated the capacity of CTP to immobilise several enzymes. To the best of our knowledge this is the first time that this ceramic is used for the immobilisation of glucocerebrosidase.

Release studies were performed with different matrices. When the enzyme was dispersed in the ceramicalginate mixture before gel formation (matrix $\mathrm{C}$ ), the release profile seemed to be initially controlled by the diffusion of GCR from the surface of the beads, with a significant burst, followed by diffusion through the pores of the gel matrix until reaching a plateau. The overall release profile was not significantly different from what was obtained using a pure alginate matrix (matrix B), suggesting that the enzyme does not interact, to a great extent, with the embedded ceramic particles. When the enzyme was pre-adsorbed onto the ceramic powders prior to the preparation of the microspheres (matrix D) the initial burst was significantly reduced and a slower release rate was achieved. For matrix A (powders) the results were similar, suggesting that the alginate does not offer an additional resistance to enzyme diffusion.

With the different matrices proposed, distinct release kinetics can be obtained and suitable strategies can be selected depending on the final application. Some aspects remain, however, to be investigated, namely the activity of the enzyme when released from the matrices used in this work (ongoing studies). Although protein immobilisation, either by entrapment or adsorption, often results in conformational alterations that may render the protein inactive, several authors have reported improved enzyme activity and/or stability in immobilised preparations when compared to their free forms [40].

\section{Conclusions}

This study describes the preparation and initial characterisation of CTP- and HAp-alginate microspheres, which are intended to be used as enzyme delivery matrices and bone regeneration templates. The proposed methodology enabled the preparation of homogeneous microspheres with a uniform size, where the bulk properties of the ceramics were maintained, indicating that the alginate did not induce any modifications in the structure of the ceramics. Preliminary studies on the immobilisation and release of the therapeutic protein glucocerebrosidase were also performed. The enzyme was incorporated into the ceramicalginate matrix before gel formation in two different ways: pre-adsorbed onto the ceramic particles or 
dispersed in the matrix. The two strategies resulted in distinct release profiles, suggesting that, depending on the application, the more suitable one can be selected.

\section{Acknowledgements}

The authors acknowledge Dr. Clara Sá Miranda for the GCR samples, Eng. Alexandra Lemos for the zeta potential determinations, and programme Praxis XXI from the Portuguese Foundation of Science and Technology (FCT) for awarding Cristina Barrias a scholarship. This work was carried out under contract POCTI/FCB $/ 41523 / 2001$.

\section{References}

[1] Griffith LG, Naughton G. Tissue engineering: current challenges and expanding opportunities. Science 2002;295:1009-14.

[2] Hench LL, Polak JM. Third-generation biomedical materials. Science 2002;295:1014-7.

[3] Temenoff JS, Mikos AG. Injectable biodegradable materials for orthopedic tissue engineering. Biomaterials 2000;21:2405-12.

[4] Laurencin CT, Lu HH. Polymer-ceramic composites for bone tissue engineering. In: Davies JE, editor. Bone engineering. Toronto, Canada: EM Squared Inc; 2000. p. 463-72.

[5] Gauthier O, Bouler J-M, Weiss P, Bosco J, Daculsi G, Aguado E. Kinetic study of bone ingrowth and ceramic resorption associated with the implantation of different injectable calcium-phosphate bone substitutes. J Biomed Mater Res 1999;47:28-35.

[6] Dupraz A, Delecrin J, Moreau A, Pilet P, Passut N. Long term bone response to particulate injectable ceramic. J Biomed Mater Res 1998;42:368-75.

[7] Grimandi G, Weiss P, Millot F, Daculsi G. In vitro evaluation of a new injectable calcium phosphate material. J Biomed Mater Res 1998;39:660-6.

[8] Gauthier O, Boix D, Grimandi G, Aguado E, Bouler JM, Weiss $P$, Daculsi G. A new injectable phosphate biomaterial for immediate bone filling of extraction sockets: a preliminary study in dogs. J Periodontol 1999;70:375-83.

[9] Peter SJ, Nolley JA, Widmer MS, Mervin JE, Yaszemski MJ, Yasko AW, Engel PS, Mikos AG. In vitro degradation of a poly (propylene fumarate) $/ \beta$-tricalcium phosphate composite orthopedic scaffold. Tissue Eng 1997;3:207-15.

[10] Sims CD, Butler PEM, Casanova R, Lee BT, Randolph MA, Lee WPA, Vacant CA, Yamremchuk MJ. Injectable cartilage using polyethylene oxide polymer substrates. Plast Reconstr Surg 1996;98:843-50.

[11] Suggs LJ, Shive MS, Garcia CA, Anderson JM, Mikos AG. In vitro cytotoxicity and in vivo biocompalibility of poly (propylene fumarate-co-ethylene glycol) hydrogels. J Biomed Mater Res 1999;46:22-32.

[12] Suggs LJ, Krishnan RS, Garcia CA, Peter SJ, Anderson JM, Mikos AG. In vitro and in vivo degradation of poly(propylene fumarate-co-ethylene glycol) hydrogels. J Biomed Mater Res 1998;42:312-20.

[13] Frazier DD, Lathi VK, Gerhart TN, Hayes WC. Ex vivo degradation of a poly (propylene glycol-fumarate) biodegradable particulate bone cement. J Biomed Mater Res 1997;35:383-9.

[14] Kharas GB, Kamanetsky M, Simantirakis J, Beinlich KC, Rizzo A-MT, Caywood GA, Watson K. Synthesis and characterization of fumarate-based polyesters for use in bioresorbable bone cement composites. J Appl Polym Sci 1997;66:1123-37.

[15] Paige KT, Cima LG, Yaremchuck MJ, Vacant JP, Vacant CA. Injectable cartilage. Plast Reconstr Surg 1995;96:1390-400.

[16] Paige KT, Cima LG, Yaremchuck MJ, Vacant JP, Vacant CA. De novo cartilage generation using calcium-alginate-chondrocyte constructs. Plast Reconstr Surg 1996;97:168-80.

[17] Kulseng B, Skjak-Braek G, Ryan L, Andersson A, King A, Faxvaag A, Espevik T. Transplantation of alginate microcapsules. Transplantation 1999;67:978-84.

[18] Martinetti R, Dolcini L, Ravaglioli A, Krajewski A, Mangano C. Experimental study on hydroxyapatite/N-carboxymethyl chitosan fillers. In: Sedel L, Rey C, editors. Bioceramics, vol. 10. Oxford, UK: Elsevier; 1997. p. 503-6.

[19] Maruyama M, Ito M. In vitro properties of a chitosan-bonded self hardening paste with hydroxyapatite granules. J Biomed Mater Res 1996;32:527-32.

[20] Dupraz A, Nguyen TP, Richard M, Daculsi G, Passuti N. Influence of a cellulosic ether carrier on the structure of biphasic calcium phosphate ceramic particles in an injectable composite material. Biomaterials 1999;20:663-73.

[21] Ribeiro CC, Barbosa MA, Calcium-Titanium-Phosphate: a potential material to be used in the biomedical field, submitted for publication.

[22] Alamo J. Chemistry and properties of solids with NZP skeleton. Solid State Ionics 1993;63:547-61.

[23] Takahiro S, Motohiro T, Hosono H. Application of a microporous glass-ceramic with a skeleton of $\mathrm{CaTi}_{4}\left(\mathrm{PO}_{4}\right)_{6}$ to carriers for immobilization of enzymes. J Ferment Bioeng 1991;72:384-91.

[24] Gross U, Muller-Mai C, Voigt C, Mesgarian M, Berger G, Ploska $\mathrm{U}$. Tissue response in femur of rabbits after implantation of a new calcium titanium phosphate composition. Key Eng Mater 2001;192-195:383-6.

[25] Otsuka M, Matsuda Y, Fox JL, Higuchi WI, Yu D, Wong J. A novel skeletal drug delivery system for anti bacterial drugs using self-setting hydroxyapatite cement. Chem Pharm Bull (Tokyo) 1990;38:3500-2.

[26] Guicheux J, Grimandi G, Trecant M, Faivre A, Takahashi S. Apatite as a carrier for growth hormone: in vitro characterization of loading and release. J Biomed Mater Res 1997;34:165-70.

[27] Gombotz WR, Wee SF. Protein release from alginate matrices. Adv Drug Deliv Rev 1998;31:267-85.

[28] Eiselt P, Yeh J, Latvala RK, Shea LD, Mooney DJ. Porous carriers for biomedical applications based on alginate hydrogels. Biomaterials 2000;21:1921-7.

[29] Alsberg V, Anderson K, Albeiruti A, Franceshi RT, Mooney DJ. Cell interactive alginate hydrogels for bone tissue engineering. J Dent Res 2001;80:2025-9.

[30] Smidsrod O, Draget KI. Chemistry and physical properties of alginates. Carbohyd Europe 1996;14:6-13.

[31] Sivakumar M, Manjubala I, Panduranga Rao K. Preparation, characterization and in-vitro release of gentamicin from coralline hydroxyapatite-chitosan composite microspheres. Carbohyd Pol 2002;49:281-8.

[32] Qiu QQ, Ducheyne P, Ayyaswamy PS. New bioactive, degradable composite microspheres as tissue engineering substrates. J Biomed Mater Res 2000;52:66-76.

[33] Hsu FY, Chueh S-C, Wang YJ. Microspheres of hydroxyapatite/ reconstituted collagen as supports for osteoblast cell growth. Biomaterials 1999;20:1931-6.

[34] Grabowski GA, Leslie N, Wenstrup R. Enzyme therapy for Gaucher disease: the first 5 years. Blood Rev 1998;12: $115-33$.

[35] Xu YH, Ponce E, Sun Y, Leonova T, Bove K, Witte D, Grabowski GA. Turnover and distribution of intravenously 
administered mannose-terminated human acid beta glucosidase in murine and human tissues. Pediatr Res 1996;39:313-22.

[36] Ferraz MP, Monteiro FJ, Serro AP, Saramago B, Gibson IR, Santos JD. Effect of chemical composition on hydrophobicity and zeta-potential of plasma spayed $\mathrm{HA} / \mathrm{CaO}-\mathrm{P}_{2} \mathrm{O}_{5}$ glass coatings. Biomaterials 2001;22:3105-12.

[37] Lopes MA, Monteiro FL, Santos JD, Serro AP, Saramago B. Hydrophobicity, surface tension, and zeta potential measurements of glass reinforced hydroxyapatite composites. J Biomed Mater Res 1999;45:370-5.
[38] Dupuy B, Arien A, Minnot AP. FT-IR membranes made with alginate/polylysine complexes. Variations with mannuronic or guluronic content of the polysaccharides. Art Cells, Blood Subs. Immob Biotech 1994;20:71-82.

[39] Peters T. All about albumin: biochemistry, genetics and medical applications. San Diego, CA: Academic Press Inc.; 1996.

[40] Nakanishi K, Sakiyama T, Imamura K. On the adsorption of proteins on solid surfaces, a common but very complicated phenomenon. J Biosci Bioeng 2001;91:233-44. 